\title{
Cuban Treefrogs, Osteopilus septentrionalis (Duméril \& Bibron 1841) (Anura: Hylidae), and other Nonindigenous Herpetofauna Interdicted in Grenada, Lesser Antilles
}

\author{
Louis A. Somma ${ }^{1}$ and Paul R. Graham ${ }^{2}$
}

\author{
${ }^{1}$ Division of Herpetology, Florida Museum of Natural History, University of Florida, Gainesville, Florida 32611, USA (somma@ufl.edu) \\ ${ }^{2}$ Ministry of Agriculture, Lands, Forestry and Fisheries, Ministerial Complex, St. George’s, Grenada (paulgraham@spiceisle.com, paulgraham1957@gmail.com)
}

$\mathrm{T}$ he number of introduced nonindigenous species of amphibians and reptiles within the greater Caribbean, including Grenada, is escalating and has become an everincreasing critical conservation concern (Daudin and de Silva 2011; Powell et al. 2011; Powell and Henderson 2012). The amount of development, tourism, and consequent import commerce is increasing, requiring careful regulation of the pet trade and fauna introduced for biological control as well as diligence in cargo inspection. Herein we document the first records of nonindigenous Cuban Treefrogs, Osteopilus septentrionalis (Duméril and Bibron 1841), interdicted from cargo, along with recent interceptions of two species of nonindigenous lizards already established on Grenada in the Lesser Antilles.

Osteopilus septentrionalis is indigenous to Cuba and portions of The Bahamas, with nonindigenous populations established in Florida, USA, Costa Rica, and a number of islands throughout the Caribbean (Meshaka 2001, 2011; Kraus 2009; Rödder and Weinsheimer 2009; Krysko et al. 2011a, 2011b; Powell et al. 2011; Powell and Henderson 2012; Somma 2012; Rivalta González 2014). This highly invasive and potentially ecologically injurious hylid is established on several islands in the Lesser Antilles. Within the Grenada Bank, it is known only on Mustique (Kraus 2009; Powell et al. 2011; Henderson and Breuil 2012; Somma 2012; Yokoyama 2012). On 9 November 2013, an adult $O$. septentrionalis (UF-Herpetology 174214) was collected from ornamental horticultural cargo by PRG at the main shipping port in Saint George's Harbour, Grenada Island, Grenada $\left(12.047808^{\circ} \mathrm{N}, 61.748347^{\circ} \mathrm{W}\right.$, datum WGS84). Kenneth L. Krysko confirmed the identity of this specimen and those described below. On 9 December 2013, a second adult $O$. septentrionalis (UF-Herpetology 174216; Fig. 1) was collected by Stephen Cox at the same locality from similar imported horticulture. In both instances the plants originated from a horticultural business in Miami, Miami-Dade County, Florida, USA, and were destined for a resort complex under construction on Grenada Island. These are the first interdicted $O$. septentrionalis vouchered from Grenada, but do not represent an established population.

Both the Woodslave, Hemidactylus mabouia (Moreau de Jonnès 1818), and Brown Anole, Anolis sagrei Duméril and Bibron 1837, are established on Grenada. Hemidactylus

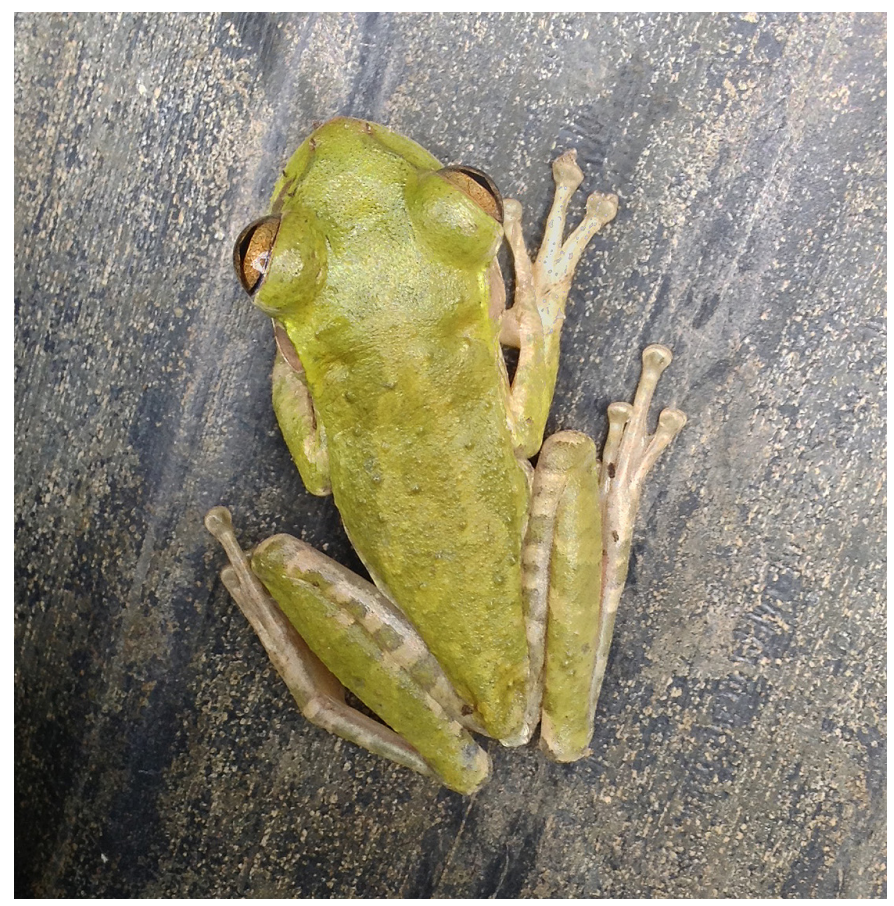

Fig. 1. Cuban Treefrog, Osteopilus septentrionalis (UF-Herpetology 174216), collected on 9 December 2013 at a shipping port in Saint George's Harbour, Grenada Island, Grenada. Photograph by Stephen Cox. 
mabouia is indigenous to Africa south of the Sahara, with invasive nonindigenous populations established throughout much of Central and South America, Mexico, Cape Verde, extralimital regions of southern Africa, perhaps Madagascar, much of Florida, USA, and numerous localities throughout the Caribbean (Powell et al. 1998, 2011; Rivas Fuenmayer et al. 2005; Carranza and Arnold 2006; Alexander and Marais 2007; Anjos and da Rocha 2008; Baldo et al. 2008; Rödder et al. 2008; Kraus 2009; Daudin and de Silva 2011; Krysko et al. 2011a, 2011b; Meshaka 2011; Rocha et al. 2011; Powell and Henderson 2012; Yokoyama 2012), including Grenada (Germano et al. 2003; Henderson and Berg 2011; Henderson and Breuil 2012). Additionally, a H. mabouia was interdicted in Maryland, USA, from a moving truck transporting household goods and furniture originating in Florida (Somma et al. 2013).

Anolis sagrei is a highly invasive dactyloid indigenous to Cuba, The Bahamas, and perhaps Little Cayman, that has numerous nonindigenous populations throughout the southern continental United States, Hawaii, Mexico, Belize, Taiwan, and portions of the Caribbean (Kolbe et al. 2008; Kraus 2009; Meshaka 2011; Powell et al. 2011; Powell and Henderson 2012; Yokoyama 2012), including Grenada (Greene et al. 2002; Henderson and Berg 2011; Henderson and Breuil 2012).

On 19 November 2013, one adult male (UF-Herpetology 174220) and three subadult $A$. sagrei (UF-Herpetology $174218,174221-222)$, in addition to one juvenile $H$. mabouia (UF-Herpetology 174219) were collected by Stephen Cox from cargo shipments of ornamental horticulture at the same locality as the aforementioned $O$. septentrionalis vouchers. These plants originated from the same plant nursery in Miami, Florida, and were destined for the same resort complex as those harboring the Cuban Treefrogs. Although both H. mabouia and A. sagrei are already established on Grenada, the transportation of additional propagules on shipping imports is a cause for concern as they may provide genetic admixture to populations already established on Grenada. This enhanced genotypic diversity may in turn enhance the adaptability of these invasive lizards (Kolbe et al. 2008).

Nonindigenous herpetofaunal introductions through cargo stowaways have become increasingly important in the greater Caribbean in recent years (Kraus 2009; Powell et al. 2011; Powell and Henderson 2012). The interceptions we describe highlight the need for increased inspector vigilance to prevent increased genotypic diversity and adaptability in already established nonindigenous herpetofauna, or to prevent new introductions of other invasive, nonindigenous species. This need is crucial in the age of mobility, increased tourism, rapid development, and trade liberalization.

\section{Acknowledgments}

We sincerely thank Stephen Cox (Plant Quarantine Officer, Grenada Customs and Excise Division) for collecting some of the vouchers and gathering data on these specimens. We are grateful to Kenneth L. Krysko (Herpetology Collection Manager, FLMNH) for verifying and curating our vouchered specimens, and helpfully reviewing our manuscript. Luciano A. dos Anjos, Robert Powell, and Alice Sanders (Division of Plant Industry, Library Technician [Retired]) provided crucial literature. We are indebted to William L. Grogan, Jr. for proofing and improving our manuscript.

\section{Literature Cited}

Alexander, G. and J. Marais. 2007. A Guide to the Reptiles of Southern Africa. Struik Publishers, Cape Town, South Africa.

Anjos, L.A. dos and C.F.D. da Rocha. 2008. A lagartixa Hemidactylus mabouia Moreau de Jonnes, 1818 (Gekkonidae): Uma espécie exótica e invasora amplamente estabelecida no Brasil. Natureza \& Conservação (Curitiba) 6:78-89.

Baldo, D., C. Borteiro, F. Brusquetti, J.E. Garcia, and C. Prigioni. 2008. Reptilia, Gekkonidae, Hemidactylus mabouia, Tarentola mauritanica: Distribution extension and anthropogenic dispersal. Check List 4:434-438.

Carranza, S. and E.N. Arnold. 2006. Systematics, biogeography, and evolution of Hemidactylus geckos (Reptilia: Gekkonidae) elucidated using mitochondrial DNA sequences. Molecular Phylogenetics and Evolution 38:531-545.

Daudin, J. and M. de Silva. 2011. An annotated checklist of the amphibians and terrestrial reptiles of the Grenadines with notes on their local natural history and conservation, pp. 259-271. In: A. Hailey, B.S. Wilson, and J.A. Horrocks (eds.), Conservation of Caribbean Island Herpetofaunas. Volume 2: Regional Accounts of the West Indies. Koninkijke Brill NV, Leiden, The Netherlands.

Germano, J.M., J.M. Sander, R.W. Henderson, and R. Powell. 2003. Herpetofaunal communities in Grenada: A comparison of altered sites, with an annotated checklist of Grenadian amphibians and reptiles. Caribbean Journal of Science 39:68-76.

Greene, B.T., D.T. Yorks, J.S. Parmerlee, Jr., R. Powell, and R.W. Henderson. 2002. Discovery of Anolis sagrei in Grenada with comments on its potential impact on native anoles. Caribbean Journal of Science 38:270-272.

Henderson, R.W. and C.S. Berg. 2011. The herpetofauna of Grenada and the Grenada Grenadines: Conservation concerns, pp. 239-258. In: A. Hailey, B.S. Wilson, and J.A. Horrocks (eds.), Conservation of Caribbean Island Herpetofaunas. Volume 2: Regional Accounts of the West Indies. Koninkijke Brill NV, Leiden, The Netherlands.

Henderson, R.W. and M. Breuil. 2012. Lesser Antilles, pp. 148-159. In: R. Powell and R.W. Henderson (eds.), Island lists of West Indian amphibians and reptiles. Bulletin of the Florida Museum of Natural History 51:86-166.

Kolbe, J.J., A. Larson, J.B. Losos, and K. de Queiroz. 2008. Admixture determines genetic diversity and population differentiation in the biological invasion of a lizard species. Biology Letters 4:434-437.

Kraus, F. 2009. Alien Reptiles and Amphibians: A Scientific Compendium and Analysis. Springer, Dordrecht, The Netherlands.

Krysko, K.L., J.P. Burgess, M.R. Rochford, C.R. Gillette, D. Cueva, K.M. Enge, L.A. Somma, J.L. Stabile, D.C. Smith, J.A. Wasilewski, G.N. Kieckhefer III, M.C. Granatosky, and S.V. Nielsen. 2011a. Verified non-indigenous amphibians and reptiles in Florida from 1863 through 2010: Outlining the invasion process and identifying invasion pathways and status. Zootaxa 3028:1-64 + MorphoBank Project No. p536 (http://www.morphobank.org/ permalink/?P536).

Krysko, K.L., K.M. Enge, and P.E. Moler. 2011b. Atlas of Amphibians and Reptiles in Florida. Final Report, Project Agreement 08013, Florida Fish and Wildlife Conservation Commission, Tallahassee.

Meshaka, W.E., Jr. 2001. The Cuban Tree Frog in Florida: Life History of a Successful Colonizing Species. University Press of Florida, Gainesville.

Meshaka, W.E., Jr. 2011. A runaway train in the making: The exotic amphibians, reptiles, turtles, and crocodilians of Florida. Herpetological Conservation and Biology Monograph (1) 6:1-101.

Powell, R. and R.W. Henderson (eds.). 2012. Island lists of West Indian amphibians and reptiles. Bulletin of the Florida Museum of Natural History 51:85-166.

Powell, R., R.I. Crombie, and H.E.A. Boos. 1998. Hemidactylus mabouia. Catalogue of American Amphibians and Reptiles 674:1-11. 
Powell, R., R.W. Henderson, M.C. Farmer, M. Breuil, A.C. Echternacht, G. van Buurt, C.M. Romagosa, and G. Perry. 2011. Introduced amphibians and reptiles in the greater Caribbean: Patterns and conservation concerns, pp. 63-143. In: A. Hailey, B.S. Wilson, and J.A. Horrocks (eds.), Conservation of Caribbean Island Herpetofaunas. Volume 1: Conservation Biology and the Wider Caribbean. Koninkijke Brill NV, Leiden, The Netherlands.

Rivalta González, V., L. Rodríguez Schettino, C.A. Mancina, and M. Iturriaga. 2014. Amphibians of Cuba: Checklist and geographical distributions. Smithsonian Herpetological Information Service 145:1-48.

Rivas Fuenmayor, G., G.N. Ugueto, A.M. Bauer, T. Barros, and J. Manzanilla. 2005. Expansion and natural history of a successful colonizing gecko in Venezuela (Reptilia: Gekkonidae: Hemidactylus mabouia) and the discovery of H. frenatus in Venezuela. Herpetological Review 36:121-125.

Rocha, C.F.D. [da], L.A. [dos] Anjos, and H.G. Bergallo. 2011. Conquering Brazil: The invasion by the exotic gekkonid lizard Hemidactylus mabouia (Squamata) in Brazilian natural environments. Zoologia (Curitiba) 28:747-754.
Rödder, D., M. Solé, and W. Böhme. 2008. Predicting the potential distributions of two alien invasive Housegeckos (Gekkonidae: Hemidactylus frenatus, Hemidactylus mabouia). North-Western Journal of Zoology (Oradea) 4:236246.

Rödder, D. and F. Weinsheimer. 2009. Will future anthropogenic climate change increase the distribution of the invasive Cuban Treefrog (Anura: Hylidae)? Journal of Natural History 43:1207-1217.

Somma, L.A. 2012. Osteopilus septentrionalis (Duméril and Bibron, 1841). In: P. Fuller (ed.), Nonindigenous Aquatic Species. U.S. Geological Survey, Southeast Ecological Science Center, Gainesville, Florida (http://nas.er.usgs.gov/queries/FactSheet.aspx?speciesID=57).

Somma, L.A., K.L. Krysko, and W.L. Grogan, Jr. 2013. First state record and interdiction for the Wood Slave, Hemidactylus mabouia (Moreau de Jonnès 1818) (Gekkonidae), in Maryland, USA. Reptiles \& Amphibians 20:208-209.

Yokoyama, M. 2012. Reptiles and amphibians introduced on St. Martin, Lesser Antilles. Reptiles \& Amphibians 19:271-279. 